Jeremy Bentham, Choice Architect: Law, Indirect Legislation and the Context

\title{
of Choice
}

Michael Quinn, Bentham Project, UCL

\section{Summary}

The goal of this paper is to locate indirect legislation within Bentham's art of legislation, and to distinguish it, as far as possible, from direct legislation. Along the way, some parallels are drawn between indirect legislation on the one hand, and the Nudge theory of Thaler and Sunstein on the other. It will be argued that many expedients categorized by Bentham as indirect legislation are simultaneously exercises of direct legislation. Another set of indirect expedients acts on knowledge, and involves efforts to eliminate asymmetries of information between potential offender and potential victim by providing official standards and disseminating a plethora of factual information. Other forms of indirect legislation threaten the coherence of Bentham's theory of law, firstly by regarding all government actions as exercises in legislation, and secondly by turning the formers of public opinion into legislators. Insofar as some forms of indirect legislation operate by sleight of hand, they conflict with Bentham's commitment to transparency in the exercise of public power, reflecting a tension between reality and appearance which runs through his thought.

Keywords: Indirect legislation, Bentham, knowledge, interest, nudge.

\section{Law as Choice Architecture}

The concept of choice architecture has been popularized by Richard Thaler and Cass Sunstein. 'A choice architect has responsibility for organizing the context in which people make decisions. ${ }^{\text {' }}$ Although Bentham never used the label 'choice architect', and although Thaler and Sunstein's understanding of choice architecture differs from the interpretation of Bentham's approach to the context of choice presented here, it would be no exaggeration to describe Bentham's entire legislative project as an exercise in choice architecture, informed by the goal of maximizing happiness as experienced by the human beings who make choices in the law-governed context of political society. For Thaler and Sunstein, choice architecture is closely associated with the concept of a nudge, which is 'any aspect of the choice architecture that alters people's behaviour in a predictable way without forbidding any options or significantly changing their economic incentives'. ${ }^{2}$ For Bentham by contrast, 'organizing the context in which people make decisions', and doing so precisely by changing incentives, is the basic task of coercive, or penal law. The legislator's range of tools in

\footnotetext{
${ }^{1}$ R.H. Thaler and C.R. Sunstein, Nudge: Improving decisions about Health, Wealth and Happiness (first published 2008) new international edition (London, 2009), 3.

${ }^{2}$ Thaler and Sunstein, Nudge, 6.
} 
organizing that context certainly extend beyond penal law, and this paper will investigate those additional means, but the first point to note is that, for Bentham, to limit choice architecture to non-coercive measures is to misconceive the notion of choice.

Bentham's understanding of law centres on its function in directing actions in accordance with the will of the law-maker, while the most obvious way of modifying behaviour in accordance with that will is to increase the costs of non-compliance through the threat of legal punishment. Bentham's analysis of law retains this penal focus throughout, so that indirect legislation itself is defined as 'the several ways of preventing misdeeds otherwise than by (force of) punishment immediately applied to the very act which is obnoxious'. ${ }^{3}$ This definition makes Thaler and Sunstein's Nudge theory sound similar to indirect legislation, since it too appears to be defined precisely in opposition to coercion. Another similarity derives from their insistence that many diverse and varied actors perform the role of choice architects. Though Bentham's default perspective is that of the legislator, he too ends up by recognizing, at least implicitly, that almost everyone is in a position to issue indirect legislation. Bentham's basic identification of a law with the declaration of a will in relation to a specific action makes every such declaration potentially a law. Most such wills are excluded by the proviso that the declaration which constitutes a law must be traceable to the sovereign in a state. ${ }^{4}$ However, since the identity of the sovereign depends upon the prevalence of a disposition to obey her declarations of will, to the extent that others display a disposition to comply with our will, we are in a position to legislate successfully, especially in relation to directing the punishments inflicted by the moral sanction. ${ }^{5}$

In terms of Bentham's logic of the will, the modern choice architect's 'nudges' are to be distinguished from commands or prohibitions. In seeking to maximize their pleasures and minimize their pains, human beings face an external world occupied by other similar beings. Surrounded by other human subjects similarly situated and motivated, humans face

\footnotetext{
${ }^{3}$ Bentham to Ashburton, The Correspondence of Jeremy Bentham, Vol. III., ed. I.R. Christie (London, 1971 $(C W J B), 127$. For the abbreviations used in this issue see the list of abbreviations in the 'Editors' Introduction, 000 above. See also 'Indirect Legislation', UC lxxxvii. 2-3: 'the sovereign may be said to act against delinquency in the way of direct legislation, in as far as he contents himself with prohibiting, under such penalties as seem competent to each case considered simply by itself, the several acts which are intrinsically obnoxious to him. Under the head of indirect legislation may be comprised whatever else can be done in the way of law in subservience to the same end'; see also ibid., UC lxxxvii. 42: 'Now for preventing mischief the most ordinary, most obvious and most universal method is to endeavour to prevent the acts that have a tendency to promote it, by means of punishment drawn from the political sanction, and applied immediately to those very acts themselves. This then, may be conceived to form the business of direct or ordinary legislation: what other expedients the nature of things may offer for the promotion of the same end may be referred to the head of indirect or transcendental legislation.'

${ }^{4}$ See Of the Limits of the Penal Branch of Jurisprudence (henceforth Limits), ed. P. Schofield (Oxford, 2010 CWJB)), 24.

${ }^{5}$ See $§ 5$ below.
} 
continuously recurring situations which require them to make a choice: most basically, to move or to stay still. They must make decisions, act and react, informed by their knowledge of their own desires and of the laws of physics, and by their best guess at the intentions of others. The accuracy of that guess is significantly enhanced by the development of political society, which is governed by law. For Bentham, the distinction between political and natural society turns on the existence or non-existence of a settled habit of obedience to mandates issuing (in some traceable sense) from a particular source. ${ }^{6}$

The normative nature of much indirect legislation is best illustrated by a comparison with the normative nature of direct legislation. The classic examples of the latter are the prohibition (Thou shalt not), and its opposite the command (Thou shalt). The directive portion of direct legislation describes an action, together with a prescription in relation to it, which splits crudely into four: 'do it', 'don't do it', 'you don't have to do it', or 'you don't have to refrain from doing it'. ${ }^{7}$ The legislator's first job is to identify actions which have a consistent tendency to impose pain, and to assess in relation to each the extent to which she might eliminate or reduce them by attaching sanctions (themselves consisting in pains) to their commission, remembering always to ensure that the cure (the painful sanction), is not worse (that is produces more pain) than the disease. The fruit of this task is nothing less than a code of penal law, which is itself simply a set of prohibited actions combined with their respective sanctions (the pains which will be imposed by the state in consequence of my performing them).

Bentham reaches for a variety of metaphors in the effort to encapsulate the central task of law, which include gardening, landscaping, and building. In a brouillon for 'Projet d'un code complet des loix' (henceforth 'Projet'), Bentham referred to islands created by coercive law, and lakes within them created by permissive exceptions:

Le champ qui fait le sujet d'un corps du droit c'est une mer immense dont les actions humaines, toujours évanouissantes, toujours renaissantes, infinement diversifiées, sont les vagues. Dans cette mer les loix coercives élèvent autant isles, les lois permissives faisant exception aux loix coercives forment autant de lacs: dans lesquels d'autres des loix coercives moins étendues que les premières peuvent encore former d'autre petites isles enclavés dans les plus grandes. ${ }^{8}$

Prohibitions and commands provide signposts to the individual decision maker, which assist her in avoiding pain at the hands of the political sanction. In Bentham's topographical

\footnotetext{
${ }^{6}$ See Bentham, 'A Fragment on Government', in A Comment on the Commentaries and a Fragment on Government, eds. J.H. Burns and H.L.A. Hart (London, 1977 (CWJB)), 391-551, at 428-9.

${ }^{7}$ See Limits $(C W J B), 115-18$.

${ }^{8} \mathrm{UC}$ xcix. 153 .
} 
metaphor, water is the absence of a coercive rule, or in Bentham's lexicon, liberty. The metaphor presupposes a general initial presumption of permission, in exactly the sense contained in Hobbes's dictum that the liberties of the subject 'depend on the Silence of the Law'. ${ }^{9}$ All which is not forbidden is allowed, and in the absence of coercive sanctions everything is allowed. As Bentham himself says, 'every efficient law whatever may be consider'd as a limitation or exception, grafted on a pre-established universal law of liberty'. ${ }^{10}$ To return to the metaphor, prohibitions create islands in the sea of permissiveness, while clauses qualifying the prohibition reverse the prohibition in relation to a specific subset of modifications of the prohibited act, creating lakes in the islands. If the qualifying clause is itself qualified, the reversal of the prohibition is itself reversed, which is to say the prohibition is reinstated, with regard to a smaller specific sub-subset of the previous subset. By continuing to nest the four varieties of imperation one within another, direct legislation can become sufficiently fine-grained to encompass all modifications of conduct. In other words, the task of the Benthamic legislator, and the general task of law, is precisely that of 'organizing the context', the normative context, 'in which people make decisions'.

In this sense, Bentham's understanding of choice architecture is much broader than that employed by Thaler and Sunstein: all laws contribute to the formation of the architecture of choice. Two things might be noted. First, Bentham's metaphor relates to direct legislation, that is to penal law. In Nudge theory, there are moments when choice architecture comes close to being identified instead with modifications of the context of choice which are nonlegal, and especially with those which exploit weaknesses in the cognitive processes - or, bluntly, the irrationality — of the chooser. Like Hobbes again, Bentham rejects the idea that either direct legislation (coercive law) or indirect legislation are incompatible with choice: there is always the option to perform a prohibited act notwithstanding the threatened sanction: 'neither in the one case any more than in the other can it [i.e. legislation] of itself impose any physical necessity, but must still leave the option to those who in the two cases [i.e. direct and indirect legislation] are respectively the [subjects] [MS 'objects'] of it's mandate or prohibition.' ${ }^{11}$

\footnotetext{
${ }^{9}$ Thomas Hobbes, Leviathan, 3 vols., ed. N. Malcolm (Oxford, 2012) (first published in 1651) (The Clarendon Edition of the Works of Thomas Hobbes: Vols. III-V)), Ch. 21, II. 340, which continues: 'In cases where the Soveraign has prescribed no rule, there the subject hath the Liberty to do, or forbeare, according to his own discretion.'

${ }^{10}$ Limits $(C W J B), 129$.

11 'Indirect Legislation', UC xcvi. 257. For Bentham's apparent confusion of the 'subjects' and 'objects' of a law in this work see 000 below. See also Thomas Hobbes, Leviathan, Ch. 21, ii. 326: 'all actions which men doe in Common-wealths, for feare of the law, are actions, which the doers had liberty to omit'.
} 
Second, the primary field of action of direct legislation is prospective, that is forwardlooking. Law, the expression of legislative will trusts 'for its accomplishment to the expectation of certain events ... the prospect of which it is intended should act as a motive upon those whose conduct is in question'. ${ }^{12}$ If the legislator does her job perfectly, and if all the subjects of law are perfectly rational, there should be no offences, because the threat of penal sanctions will have altered the prudential calculation of the potential offender just sufficiently to make her refrain from an act likely to issue in net pain to her. The first evil (that is pain) of punishment is the coercion of the law-abiding, that is 'the pain which it gives a man not to be able to do the act ... which by the apprehension of the punishment he is deterred from doing'. ${ }^{13}$ The idea that penal law functions only retrospectively is frankly absurd: how on earth is such law supposed to guide conduct? 'The general object of all laws is to prevent mischief': ${ }^{14}$ not to punish, but to prevent. The first end of penal law is to 'prevent ... all sorts of offences whatsoever: in other words, so to manage, that no offence whatsoever may be committed'. ${ }^{15}$ It is in this sense that every actual application of a penal sanction is evidence of the imperfection of the penal law: 'The mischief must ... have already taken place before the remedy can be applied. ... Every instance therefore in which the remedy comes to be applied ... adds to the instances in which it is inefficacious: and ... tends to render it unprofitable. 16

This statement has been interpreted as the beginning of Bentham's endeavour to identify means of influencing conduct which do not suffer from this weakness, which, that is to say, eschew the threat of state-inflicted punishment as an operative means. One of the strengths of such a view is that it seems to offer a straightforward distinction between direct and indirect legislation: the former relies on such punishment, while the latter does not. ${ }^{17}$

\footnotetext{
${ }^{12}$ Limits $(C W J B), 24-5$.

${ }^{13} I P M L(C W J B), 163$. Note that this pain is distinct from the pains which follow from the actual infliction of punishment, and that such actual infliction of punishment is not a necessary condition for its existence.

${ }^{14}$ Ibid., 165.

15 Ibid.

16 'Indirect Legislation', UC 1xxxvii. 42.

${ }^{17}$ See S.G. Engelmann, 'Limits and Indirect Legislation', in The Legal Philosophy and Influence of Jeremy Bentham: Essays on Of the Limits of the Penal Branch of Jurisprudence, ed. G. Tusseau (London, 2014), 30815, at 309: 'Indirect Legislation is indirect because it involves action ... on the part of the legislator, but the instrument of this action is not isolable as a specific political sanction, in the form of punishment ... . Its way of working is instead to activate and direct or redirect the popular/moral and religious sanctions'; M. Bozzo-Rey, 'From Indirect legislation to Nudge: A Possible Way to Understand Bentham's Normative Framework' (Unpublished paper delivered at the $13^{\text {th }}$ conference of the International Society of Utilitarian Studies, Yokohama National University, 2014): 'What is at stake through indirect legislation is not punishment. It happens too late, it is too expensive and it doesn't allow a subsequent identification of deviation or inadequacy to legal norm. What is at stake through indirect legislation is prevention'; A. Brunon-Ernst, 'Indirect Legislation and Utility: A study of the effectiveness of Indirect Legislation' (Unpublished paper delivered at ISUS 13, YNU,
} 
Bentham himself seems on occasion to advance just this distinction between the two ${ }^{18}$ It will be argued that as a description of some of the measures which Bentham categorizes as indirect legislation, this interpretation is correct. However, in relation to others similarly categorized it is not.

Bentham provides several general characterizations of indirect legislation, one of which begins: 'Indirect Legislation is employed to advantage on one or another or all of these 3 accounts - $1^{\text {st. }}$ the conquering an Evil at a less expence of Punishment than could be done in the direct way. ${ }^{\prime 19}$ Note, at less expense of punishment (where less expensive means inflicting less pain), not at no expense of punishment. In a brouillon for 'Projet', under the heading 'Indirect. Beginning', Bentham wrote: 'Prévenir les délits sans peine, ce seroit produire un effet sans cause, c'est la poudre blanche qui chasse un boulet sans bruit. On ne servoit s'en passer, mais on peut aider leur efficacité. Or thus: Se passer de loix pénales, c'est ce qui est impossible. ${ }^{20}$ In 'Indirect Legislation' he noted: 'Indirect legislation may assist direct, but can not supersede it. The one and the other must go hand in hand. The events which call for the infliction of punishment may be more rare: but punishment must always be held up. ${ }^{21}$ Few commentators would assert that Bentham wanted to do away with penal law and replace it entirely with something else, which he called indirect legislation. ${ }^{22}$ Given that punishment is pain, and therefore evil, it is certainly true that Bentham's legislator should consider penal prohibition as a last resort, only justifiable by its exclusion of 'some greater evil'. Non-penal modes of law-making and of prompting compliance-that is of enforcing the legislator's will—-should be pushed to their limits before new offences, and new punishments, are created. However, the primary definition of law involves coercion for Bentham. As he noted, in relation to the order in which his Codes of Law should appear: 'C'est la partie pénale qui est la clef de toutes les autres: c'est à elle qu'elles aboutissent: c'est n'est que par elle qu'on peut les expliquer'. ${ }^{23}$

Given that 'Indirect Legislation' was written in continuation of IPML, and that IPML was conceived as a preface to a penal code, the focus of the former on prevention of offences

2014): 'Contrary to direct legislation, indirect legislation is not grounded in legal punishment. Indirect legislation deals with incentives and prevention, not punishment.'

${ }^{18}$ See note 3 above.

19 'Indirect Legislation', UC xcvi. 255.

${ }^{20}$ UC xcix. 160.

21 'Indirect Legislation', UC lxxxvii. 11.

${ }^{22}$ Mary Mack is a notable exception in this regard. See Jeremy Bentham: An Odyssey of Ideas, 1748-1792 (London, 1962), 291-322, at 306: 'In the far distant future the moral sanction will inevitably overtake and ultimately replace the political.'

${ }^{23}$ UC xcix. 160. Emphasis added. See also Limits $(C W J B), 213$ : 'upon the plan here given of the law, every thing that is or can be done by law supposes an offence'; and also ibid., 182. 
is understandable. However, the division between direct and indirect legislation is by no means confined to the sphere of penal law. After listing some traditional divisions of law (national v. international, civil v. penal, private v. constitutional, procedural v. substantive), Bentham states 'Each of these may be distinguished into direct or ordinary, and indirect or preventive. ${ }^{24}$ In 'Indirect Legislation' he devotes a Chapter to indirect legislation in Constitutional Law. Across all these fields, the definitional primacy of the penal persists: indirect legislation consists in legislative acts which do not operate solely by the prohibition of acts deemed mischievous.

\section{Directly Indirect: Modifying the interests of non-offenders}

A significant portion of Bentham's indirect legislation consists in ordinary direct legislation considered from a different perspective. As Bentham noted in a further brouillon for Projet, in considering different ways to divide the logical whole that was law:

J'appelle loix directes celles qui vont directement à leur but: savoir par exemple défendre ou ordonner l'acte même, dont on a affaire quand il s'agit du droit pénal, arrêter expressement qu'un droit de propriété ou d'office sera en telles ou telles mains quand il s'agit du droit civil ou du droit constitutionnel. Toute autre façon d'agir peut être appellée indirecte. La même loi qui est directe à un égard, par rapport à tel fin, est indirecte par rapport à un autre. ${ }^{25}$

This dual identity is most obvious in the identification of, and attachment of penal sanctions to, accessory offences. The relevant indirectness here relates in no way to the absence of penal sanctions, but rather to the manner in which those sanctions do not apply to the potential performer of a particular mischievous action which the legislator wishes to prevent, to which she may have already attached a penal sanction by means of direct legislation, and which Bentham termed 'the principal offence'. Instead, the principal offence, and its potential perpetrator, may not be mentioned in the new exercise of direct legislation, which creates a new offence, and threatens a new sanction.

\footnotetext{
24 'Indirect Legislation', UC 1xxxvii. 2.

${ }^{25}$ UC xxxiii.111-12. Bentham made a similar point in text drafted for 'Projet Forme', one of the two parts into which Bentham appears to have divided 'Projet', and which Dumont presented as 'Vue générale d'un corps complet de législation', Traités, I, 141-370 (Traités 2010, 65-158; Bowring, III. 155-210). See UC xxxiii. 114 (Traités, I. 150 (Traités 2010, 67; Bowring, III. 158)): 'Dixième division. Loix directes, loix indirectes. On pourroit appeller directes, celles qui vont directement à leur but: c'est à dire qui ne font qu'ordonner ou défendre tout simplement l'acte même qu'il s'agit de faire naître ou de prévenir. J'appelle indirectes celles qui y visent à l'aide de moyens plus ou moins lointains, en s'attachant à d'autres actes qui ont une liaison plus ou moins immédiate avec le premier. Ce sont ci qu'on a en vue quand on parle de moyens dont peut se servir un législateur comme tel pour prévenir les crimes. Cependant comme une loi ne sauroit exister sans un acte qui en est l'object, il faut qu'une loi qui est indirecte par rapport à tel acte soit directe par rapport à tel autre. Les épithètes direct et indirect ne sont juste qu'autant qu'on rapporte à un seul et même acte deux ou plusieurs loix différentes.'
} 
It might help to look at how Bentham sets up the task of the legislator at the beginning of 'Indirect Legislation'. The goal of the legislator is to influence action, or to conduct conduct. ${ }^{26}$ There are three necessary and sufficient conditions for voluntary actions on the part of human agents. With Bentham: 'Inclination, knowledge, power: these are the three points to one or other of which every expedient which can be made use of in the view of influencing a man's conduct must apply itself. In these three words we have the sum and substance of the scope and limits of every thing that can be done in the way of legislation, direct and indirect put together.' 27

$[\mathrm{C}]$ onceive a man to possess all these three endowments with relation to any act, and the act follows necessarily ... for such is the force of these expressions: will or effectual inclination to cause the act to take place, knowledge of the means or expedients requisite for that purpose, and power to set these expedients to work: suppose any of them to be wanting to him, and the act ... cannot take place. ${ }^{28}$

One difference between direct and indirect legislation involves a shift in legislative focus. Direct legislation operates against an offence by acting on the interest or inclination, that is the will, of the potential offender. Many measures of indirect legislation simply broaden the focus to operate on the interest, knowledge, and power of persons other than the potential perpetrator of the principal offence. ${ }^{29}$

From the perspective of the agent considering committing the principal offence, these laws are not direct: they make no attempt to modify her calculation of interest by appointing a new sanction, or by increasing an existing sanction, against her. However, from the perspective of the parties whose assistance or forbearance may be necessary conditions for

\footnotetext{
${ }^{26}$ See M. Foucault, 'The Subject \& Power', in Power, ed. J.D. Faubion, (New York, 2000) (The Essential Works of Foucault, 1954-84, Vol. III), 326-48, at 341: "To "conduct" is at the same time to "lead" others (according to mechanisms of coercion that are, to varying degrees, strict) and a way of behaving within a more or less open field of possibilities. The exercise of power is a "conduct of conducts" and a management of possibilities. Basically, power is less a confrontation between two adversaries or their mutual engagement than a question of "government".'

27 'Indirect Legislation', UC lxxxvii. 3.

${ }^{28}$ Ibid., UC lxxxvii. 7.

${ }^{29}$ Bentham's language is not entirely consistent, but it seems that such measures are not indirect merely in the sense of having collateral consequences not mentioned in the statement of the law (as, for instance, an increase in sales of non-alcoholic beverages might result from a prohibition on selling alcohol). If this was all Bentham meant to capture by indirect legislation, then his categorization looks too porous to be useful, since the distinction between direct and indirect legislation has evaporated: practically every direct law has indirect effects. That said, he certainly believed that one law might contribute simultaneously to the achievement of plural ends, and that, since law was essentially coercive, the more ends that were served by a given law the better: 'All measures of the coercive cast - that is all legislative measures but those which consist in the modification or abrogation of existing ones - involve what may be termed vexation (for all coercion is productive of vexation) in their result: avoidance of vexation being absolutely impossible, there remains only this problem - viz: from a given necessary quantity of political vexation, to extract as much political advantage as possible, in all imaginable shapes.' ('Introductory Observations on the Police Bill', UC cxlix. 150)
} 
her enjoyment of the spoils of the offence, these laws are utterly direct: they operate in exactly the same manner as any other penal law, which is, with Bentham:

Leaving the Physical power in its full force, and leaving the original interest in it's full force, to raise up an artificial interest which shall (that is in his eyes) outweigh it: it is by this means that the apparently preponderant interest becomes wanting-And this is the work of Direct Legislation. ${ }^{30}$

Bentham repeatedly states that the creation of accessory offences is a form of indirect legislation against the principal offences to which they are respectively accessory, ${ }^{31}$ but creating offences and attaching penal sanctions to them is the very essence of direct legislation.

What makes such examples indirect legislation is not the absence of penal sanctions: without their direct application to accessory offences, the calculation of the putative perpetrator of the principle offence would be unaltered. It is the engagement, by means of direct legislation, with the interest of the potential accessory which indirectly affects the calculation of that potential perpetrator. The behaviour of those accessories is influenced in exactly the same manner as the behaviour of the perpetrator herself is influenced by the penal sanction threatened against the principal offence itself. Because of the new penal sanctions threatened directly against them, such accessories will be less likely to offer the perpetrator assistance. The legislator will have succeeded in modifying the perpetrator's calculation by creating an artificial interest on the part of those accessories, which did not exist before. She will have reduced the power of the offender by changing the interests of others. ${ }^{32}$

Another law which addressed the power of the offender indirectly by acting directly on the interest of others was the statute of Edward I which ordered the clearing of vegetation within 200 feet of a public highway. ${ }^{33}$ The aim of the law was to reduce the incidence of robbery, by denying potential hiding-places to robbers hoping to ambush travellers. Bentham

\footnotetext{
30 'Indirect Legislation', UC xcvi. 260.

${ }^{31}$ See 'ibid., UC lxxxvii. 29: 'Now the ordinary and most obvious method of applying that force [i.e.the force of the political sanction] is to prohibit the very act which is obnoxious, and as a means of enforcing prohibition, to punish the very act which happens to appear obnoxious, and that without regard to any other. But this is the business of direct and ordinary legislation. To the management of the force of the political sanction in the way of indirect legislation may be referred every thing else that can be done by the legislator without making any special use of the principle of benevolence or of any of the other sanctions.' See also ibid., UC xcvi. 255; lxxxvii. 172-6; 178-9.

32 Bentham states unambiguously that this is a mode of indirect legislation: 'Leaving the interest in force, to take away or at least to weaken the Physical Power, and this either by taking off the requisite auxiliaries, or by raising up opponents to the offender-And this also is the work of Indirect Legislation.' 'Indirect Legislation', UC xcvi. 260 (emphasis added). The same characterization is applicable to a range of direct penal laws: see ibid., UC xcvi. 254; lxxxvii. 191.

3313 Edward I. Stat.2, c.5 (1285).
} 
calls it 'Indirect Legislation reversed', ${ }^{34}$ which is a revealing comment. A piece of indirect legislation aimed at the same end might have made failure on the part of landowners to clear trees in the vicinity of the road an offence, and attached a penal sanction. Instead, Edward's act simply inflated the definition of felony to swallow such failure, thereby extending the penalty for any felony committed on a road not cleared of trees to the owner of the land over which the road passed. Edward's Act might well have deterred landowners from allowing the verges of roads to become dense with vegetation, but it did so not by creating a new offence with a new sanction, but by declaring the landowner guilty of any robbery committed on the road passing over his land. ${ }^{35}$

Further cases may be discerned in the English Statutes limiting the amount of gunpowder an individual might hold, or the number of horses used to draw vehicles on the road. In these cases, direct legislation creates new offences (accompanied by penal sanctions) consisting in possessing gunpowder or in using horses in excess of the prescribed maximum quantities, while amongst the ends indirectly aimed at, according to Bentham, in addition to the avoidance of damage to roads and the prevention of accidents, might be the preservation of social peace through rendering rebellion more difficult. ${ }^{36}$

Hope of further clarification seems to be offered by Bentham's insistences that, first, 'Direct Legislation is where the secondary Will has the same person for it's object as the primary: Indirect, where it has some other' ${ }^{37}$ and second, that 'A law operates in the way of Indirect Legislation; when it's secondary will respects not the same object as the primary one does' ${ }^{38}$ However, these statements require interpretation, for two reasons. First, it is clear from Limits that by 'subjects of a law' Bentham means either persons or things, whereas by 'objects of a law' he means acts. ${ }^{39}$ The first quotation then, seems to feature a slip, insofar as a law cannot have a person for its object, but only an act. Second, the distinction between

\footnotetext{
34 'Indirect Legislation', UC xcvi. 255.

${ }^{35}$ Further, Bentham considers a 'Law giving a monopoly of certain businesses to Women', as indirect legislation against prostitution ('Indirect Legislation', UC xcvi. 254). The direct law here would create an offence, accompanied by a penal sanction, and consisting in the exercise of that profession by a man. Bentham views prostitution as the last resort of exploited and abandoned women, exposed to risk of indigence from the loss of their good name. Excluding men from midwifery, for instance, would increase the opportunities of profitable employment for women, and thereby increase their power, and divert some of them from having to sell their sexual favours to keep body and soul together, a decision itself liable to bring in train significant pains. See also Writings on the Poor Laws: Vol. I, ed. M. Quinn (Oxford, 2001 (CWJB)), 107-14; Writings on the Poor Laws: Vol. II, ed. M. Quinn (Oxford, $2010(C W J B)$ ), 52-4; Of Sexual Irregularities, and other writings on Sexual Morality, ed. P. Schofield, C. Pease-Watkin, and M. Quinn (Oxford, 2014 (CWJB)), 100-1, 138-40. 36 'Indirect Legislation', UC lxxxvii. 94. The Statutes in question were respectively the Gunpowder Act (12 Geo. III, c. 61) and the General Highways Act (13 Geo. III, c. 78).

37 'Indirect Legislation', UC xcvi. 257.

${ }^{38}$ Ibid., UC xcvi. 254.

${ }^{39}$ Limits (CWJB), 62-3.
} 
primary and secondary will does not feature in the near contemporaneous Limits. It does, however, appear in Bentham's manuscripts of the same period, in a passage headed 'Parts of a Law_Will primary and Secondary_illustrated':

If you say to your Son, 'My child, get your lesson', you have expressed but one will: there is but one will of yours in the case; and that is, that he should get his lesson.

But if you suspect he may not get his lesson, tho' you have bid him, and say 'my child, get your lesson, or John shall whip you', there are 2 wills of yours expressed: the $1^{\text {st }}$ is, and which alone was the occasion of your forming the $2^{\text {nd }}$, as before that he get his lesson; The $2^{\text {nd }}$ is, and what you would never have thought of, but for the sake of the other, that if he will not get his lesson, John should whip him. ${ }^{40}$

The secondary will is therefore that which is contained and expressed in what Bentham calls subsidiary laws, or in generic terms, adjective law. This reading is borne out in the example which Bentham gives in 'Indirect Legislation' after introducing the distinction, which concerns the pain involved in the Gin craze of the 1730s:

The Legislature saw this wretchedness and lamented it - What, said they, is the cause? Excessive drinking of this liquor-What then would be the remedy? To will that the liquor should no longer be so drunken. Here then was formed the primary will.-Here was the declaratory part, the Substantive of a Law forbidding it-'Drink not this liquor to excess'. But send this precept abroad among the people, was it likely to be obeyed? No, certainly. ... Addressed to an unfeeling populace, opposed by propensities thus powerful, a naked Direction would be but an object of derision.- - To do any thing it must be compleated into a Law - it must be furnished with ... a Sanction denouncing Punishment. How then? With what sort of Sanction? How applied? To whom addressed? To the person whose act it is that it is purposed to prevent? That would be in vain. ...

To provide a Sanction - a Punishment - thus addressed would therefore be to no purpose - the Punishment never could be inflicted - if never inflicted it would be known never to be inflicted: and if known never to be inflicted it would be as nothing. This Sanctional part therefore would do nothing for the directory: and the directory part of itself would do nothing. ... If therefore he is at all to be influenced by the Law it must be by means of a Sanction addressed to some one else. The attack must be made upon some other quarter. ... This poison, once it gets to a man's throat, there is no help for it—down, if he pleases, it must go-But whence comes it to him? ... He gets it from the publican-And how? By paying for it. ... If then for this quantity of money the Publican should refuse to sell more than half the quantity of Gin, would the consumer any longer get the whole? No, it should seem, but half.

When the Indirect plan of Legislation is adopted, that is when the secondary will is not that which can be addressed to him whose conduct it is the scope of the primary will to regulate, the primary will remains in fetters. It governs the measures of the

\footnotetext{
${ }^{40} \mathrm{UC}$ lxx. 6. Guillaume Tusseau uses this quotation in reaching the same conclusion as to the meaning of primary and secondary wills: see 'An Old English Tale: Bentham's Theory of the Force of a Law', in The Legal Philosophy and Influence of Jeremy Bentham, 80-129, at 98.
} 
Legislator: that is it assigns the modes of the several auxiliary wills that are to be brought forth to supply the place which the secondary will regularly would have occupied: but it is not, at least it is not necessarily, promulgated to the people. ${ }^{41}$

Making gin drinking an offence will not work (and even if it did 'work' would be unprofitable by causing more pain than it prevented). Under such a law, a series of mandates (instructing police, judges, gaolers and so on) would express the secondary will, which itself consisted in the desire that steps be taken to apply penal sanctions to enforce the primary will. A duty on the distilling and sale of gin however, will work, since distillers and retailers will pass on the duty to customers, and many customers will opt, or have no option but, to reduce their consumption of gin. The penal sanction (that is the tax) applies not to the consumer but to the supplier. The status of taxes as direct or indirect legislation is an issue to which we will return, but, for present purposes, the point is that the legislative levers which ended the gin craze were indirect in the sense that they did not take the direct route of banning consumption, but the indirect one of taxing its supply. Those responsible for paying the duty (that is those whose calculation of interests was directly altered) were not the buyers but the sellers of gin.

Three further examples conclude this section. First, there is no doubt that penal laws prohibiting wantonly cruel treatment of animals are examples of direct legislation. However, considered in a different light, they are also measures of indirect legislation: 'To restrain man from tormenting the inferior part of the animal creation, is a measure of indirect legislation ... : a direct law against cruelty to animals would be an indirect law against cruelty towards men. ${ }^{42}$ Second, the entire apparatus of subsidiary or adjective law, much of which consists in direct legislation, is simultaneously indirect legislation in its relation to the primary or substantive law to which it is subsidiary or adjective: 'Laws Adjective, may be considered as Articles of Indirect Legislation framed against the acts prohibited by the several Substantive Laws to which those Adjective Laws are appendages'. ${ }^{43}$ Third, the complex construction constituting the English poor laws - which in the vocabulary of direct legislation encompassed the provision of rewards (the negative pleasure of being secured against starvation), the imposition of obligations (the pain felt by the owners of property liable to pay the poor-rates), and a raft of subsidiary and procedural regulations - might be designated indirect legislation against crimes arising from the threat of starvation. ${ }^{44}$ Indeed, by analogy from these examples, the entire apparatus of direct legislation which prohibits

\footnotetext{
41 'Indirect Legislation', UC xcvi. 258-9 (Emphasis, excepting the final instance, added).

42 Ibid., UC lxxxvii. 27.

43 Ibid.

${ }^{44}$ See ibid., UC xcvi. 256; Writings on the Poor Laws: Vol. I (CWJB), 10.
} 
offences against person and property, which, that is, creates security, might equally well be considered as indirect legislation in relation to two closely allied subordinate ends, namely subsistence and abundance:

Enjoyment is the offspring of wealth-wealth of labour. What men want from government is - not incitement to labour — but security against disturbance:- security to each, for his portion of the matter of wealth, while labouring to acquire it, or occupied in enjoying it. For the purpose of encreasing wealth, individuals require neither to be forced to labour, nor allured. The want of that which is not to be had without labour, is sufficient force: the assurance of being able to enjoy it is sufficient allurement. $^{45}$

\section{Levelling the playing-field: Eliminating asymmetries in knowledge}

A further set of measures of indirect legislation involves a primary focus on knowledge, rather than interest or power. The successful execution of many crimes depends upon an asymmetry in knowledge between perpetrator and potential victim. In general these measures address the interest of the potential offender indirectly, by eliminating that asymmetry. Directly, such measures increase the knowledge available to potential victims, thereby making success more unlikely for the perpetrator, because the pre-existing interest and power of potential victims, joined to their increased knowledge, will 'raise up opponents' to the would-be offender. 'The artifices of the ill-designing are of no avail any further than as they are unknown'; and 'Enterprizes to the success of which the concealment of the design is necessary, if concealment is hopeless, are not embarked in'. ${ }^{46}$ Once again, the would-be offender's calculation of interest — is it worth my while to commit the crime? - is materially altered by means which do not threaten any new penal sanctions against her, but which work first by increasing the knowledge of others, and then by making her aware that their knowledge has been increased. As Laval notes in his magisterial discussion, Bentham's rationale for his recommendation of the tattooing of the entire population with identity marks is identical: 'In short, it would be necessary to invent a human equivalent of the "certificate of authenticity" that Bentham advocates for products. ${ }^{47}$

Notwithstanding his general endorsement of laissez-faire in political economy, Bentham made an exception with regard to provision of knowledge, and considered many

\footnotetext{
45 'Method of an Institute of Political Economy' (henceforth 'Institute'), UC xvii. 309 (10 March 1804) (Jeremy Bentham's Economic Writings, ed. W. Stark, 3 vols. (London, 1952-4), III. 323-4). See also Bentham's comment in preparatory materials for the second edition of Defence of Usury, in Writings on Political Economy: Vol. I, ed. M. Quinn (Oxford, $2016(C W J B))$, 145: 'The increase of wealth is not the business of the Chancellor of the Exchequer but of the $\mathrm{L}^{\mathrm{d}} \mathrm{H}$. Chancellor and the other Judges.'

46 'Indirect Legislation', UC 1xxxvii. 97; 92.

${ }^{47}$ C. Laval, 'The Invisible Chain: Jeremy Bentham and Neo-liberalism', this issue, 000.
} 
measures of this sort, ${ }^{48}$ including both the dissemination of factual information, and provision of general standards of measurement and of quality. He lists thirteen separate heads of the sorts of knowledge which government might disseminate, extending from standards of weights and measures, through standards of quality in relation to merchandize, certification and registration of titles to (and transfer of) property and to specific legal status, certification of birth and death, and certification that a requisite duty has been paid, to publication of current prices. ${ }^{49}$ Bentham consistently viewed the role of government in the collection and dissemination of information in two complementary ways. On the one hand, the more information the legislator collected, the better the basis for her calculation of the consequences of policy. On the other, the more information about her own actions the legislator published, the better placed the public to evaluate those actions and avert misrule. ${ }^{50}$ His focus in this branch of indirect legislation is different, and concerns the dissemination of information with a view to enabling all of us to avoid falling victim to deception by our fellows. All these measures aim to facilitate trust. Thus the establishment of standard measures facilitates trust in that buyer and seller are using an identical metric; the establishment of standards of quality performs the same function by providing a guarantee of quality; the provision of standard forms of title to property, and registration of titles thereto, makes it possible for buyers to trust that sellers do indeed own the property in question.

Bentham remains agnostic as to whether the goal of uniform standards of quantity should be achieved by direct legislation: 'The one [course] is to provide ... the requisite standards and to forbid the use of any others; the other is to provide the standards themselves, and leave it to general convenience to provide for their adoption'. ${ }^{51}$ Initially, he seems to favour the latter option, but goes on to leave open the possibility of using direct legislation, and then deploys a favourite technique, the status of which is less clear:

[I]f I thought any sort of coercion necessary I would impose penalties on any workman who after a certain time should make a weight or measure otherwise than according to the standard. If I thought it worth while to endeavour to compass the point on the sudden, I would ... invalidate all dealings in which any other weights or

\footnotetext{
${ }^{48}$ See, for instance, 'Institute', UC xvii. 322, 310-11 (11 March 1804) (Jeremy Bentham's Economic Writings, III. 336-8).

${ }^{49}$ In his enumeration he uses the verbs 'Institute', 'Require', 'Permit', 'Furnish' and 'Publish'. Twice he uses the expression 'Requiring or permitting'. Now, requiring and permitting are acts of Direct Legislation: if the legislator requires something he attaches a penal sanction to failure to perform a corresponding act. Similarly, if I am legally permitted to perform an act, others are placed under an obligation to refrain from preventing me from performing it.

${ }^{50}$ See D. Lieberman, 'Bentham's Jurisprudence and Democratic Theory: an alternative to Hart's approach', in Bentham's Theory of Law \& Public Opinion, ed. X. Zhai and M. Quinn, (Cambridge, 2014), 119-42 at 141-2. 51 'Indirect Legislation', UC 1xxxvii. 155.
} 
measures than those appointed by authority were employed. The first expedient I should be apt to think would be sufficient. ... At any rate it would with the assistance of the second ${ }^{52}$

In other words, he would consider direct legislation, and back it up with a measure which does not directly command under threat of penalty, but simply withdraws the backing of the law for the enforcement of any contract not drawn in the metric of the new standard. This limiting or exceptive clause involves the reversal of the direct penal laws usually applied to contracts, in that, in relation to all contracts covered by the exceptive clause, it abolishes legal liability and application of the legal sanction.

With reference to the prevention of fraud of all sorts, Bentham notes that he lacks space and time to 'go in search of every thing that might be done by authority of government to establish proper standards of quality and value for the infinite variety of articles that might be susceptible of such trial' ${ }^{53}$ Having anticipated in spirit the rationale for the entire apparatus of trading-standards authorities, public and environmental health inspectors and the like, Bentham retreats, concluding that, 'For the law to oblige persons at large to employ standards of this kind at all is perhaps in no instance either practicable or worth while'. ${ }^{54}$ However, he recommends that every trader should, having had an interest in compliance created by direct legislation, display prominently a set of instructions detailing common methods of fraud in that trade. In the same vein, Bentham thought it reasonable for the legislator to consider 'furnishing the people with cautionary instructions putting them on their guard against several modes of defraudment and other species of delinquency' ${ }^{55}$

In relation to certificates of title to property, Bentham first advises the legislator to provide good models; second, views the invalidation of all certificates which fail to follow the model as a legitimate option; and, finally, recommends the mandatory registration, on pain of nullity, of all evidences of title 'in the genuineness and publicity of which third persons may have an interest'. ${ }^{56}$ The choice between the options of a direct penalty, the sanction of invalidity, and no sanction at all should in each case be determined by an utilitarian calculation of the least painful manner of meeting the needs of the day. Sometimes,

\footnotetext{
${ }^{52}$ Ibid., UC 1xxxvii. 156.

${ }^{53}$ Ibid.

${ }^{54}$ Instead, he recommends that government should promote the discovery of new tests of quality, convey 'intelligence of them to the notice of the people', and finally ensure that 'the officers of government shall avail themselves ... of such tests as shall have been discovered'.

55 'Indirect Legislation', UC lxxxvii. 153.

${ }^{56}$ Ibid., UC lxxxvii. 162.
} 
the sanction of invalidity will be unnecessary, since often provision of a good model will be sufficient:

Instructions given by government to the effect above suggested, even though each were left at liberty to adopt them or not as he thought, would not by any means be useless. In matters of this sort people are ready enough in general to follow the patterns that are set before them by authorities much inferior to that of the legislature. Were such advice then to be given, the probability is that in general it would be taken: especially if the compliance with it were to be enforced by some trifling penalty imposed upon the party in fault, not upon persons as yet unborn as is oftentimes the case where it consists in the invalidation of the instrument. ${ }^{57}$

This expedient brings us close to the terms in which Sunstein and Thaler couch a central aspect of Nudge theory. ${ }^{58}$ Not only is 'following a pattern set before me' what I do when I accept a default option, but the idea of compliance being enforced by a 'trifling penalty' is absolutely in the spirit of nudge ${ }^{59}$ In effect, to provide officially approved patterns, or default options, is to frame a question or issue in a particular way, which the framer presumably approves. ${ }^{60}$

Some of these measures would involve direct legislation, creating new offences, while others would not. Even where no direct legislation was involved (beyond, that is, the imposition of coercive taxation necessary to fund the provision of information), the governmentally underwritten availability of factual information about people, products and practices might avert significant pains, and facilitate production of significant pleasures. I have noted elsewhere that, at least in part, indirect legislation seems sometimes to be in danger of running counter to Bentham's advocacy of transparency, ${ }^{61}$ and more will be said on this in $\S 5$. However, no such tension is apparent in the expedients detailed by Bentham under the head of knowledge, where indirect legislation depends for its efficacy on the twin Benthamic virtues of transparency on the one hand, and promulgation or dissemination on the other.

\footnotetext{
${ }^{57}$ Ibid., UC lxxxvii. 160 (Emphasis added).

${ }^{58}$ See Thaler and Sunstein, Nudge, 8-9, 93-5.

${ }^{59}$ See ibid., 6, and 000 above.

${ }^{60}$ For Bentham's conscious use of framing see, for instance, Supply without Burthen; or Escheat vice Taxation: Being a proposal for a saving of taxes by an extension of the law of escheat, including strictures on the taxes on collateral succession comprised in the budget of 7th December 1795 (London, 1795), 32-3 (Bowring, ii. 58598, at 590; Jeremy Bentham's Economic Writings, I. 279-310, at 292-3); and for discussion see M. Quinn, 'Jeremy Bentham, “The Psychology of Economic Man” and Behavioural Economics', Economia 6 (2016), 3 32 , at $17-19$.

${ }^{61}$ See Quinn, 'Popular Prejudices, Real Pains: What is the Legislator to do when the People err in assigning Mischief?', in Bentham's Theory of Law and Public Opinion, 62-89 at 82.
} 
The choice architecture of Sunstein and Thaler also operates in part by removing asymmetries of information, such as in the requirement that companies disclose the quantity of toxic chemicals released during their productive process. For them, the institution of a mandatory Toxic Release Inventory 'is a nice example of a social nudge'. ${ }^{62}$ However, as Housman and Welch point out, a policy of mandatory disclosure and publication of information is 'coercive' (it is, in Bentham's terms, direct legislation). ${ }^{63}$ Sunstein and Thaler count this as a nudge because the sanction consists in loss of public approval, and thereby of profit, so that the sanction is imposed not by government but by public opinion. That the facilitation of the operation of the moral sanction forms part of the armoury of indirect legislation has never been in doubt, but even this law, which empowers the moral sanction, is, from the perspective of the polluting companies involved, impeccably direct, insofar as disclosure of their emissions is made obligatory.

What would Bentham think of nudge theory? I have argued elsewhere that Bentham recognized many of the cognitive failings, including status quo bias, the desire for cognitive ease and the susceptibility to framing, which provide the rationale for Thaler and Sunstein's libertarian-paternalism. ${ }^{64}$ It is entirely likely that he would heartily endorse many of their policy prescriptions, ${ }^{65}$ and indeed see a case for going beyond many of them. The most obvious case, perhaps, concerns the default option in relation to the disposal of usable organs after death. Thaler and Sunstein have some sympathy for the proposal to change the default assumption with regard to the deceased individual's willingness or unwillingness for her organs to be used for the medical benefit of others from negative to positive. Instead of explicitly opting-in to organ donation programmes, I would be required explicitly to opt-out. In Austria, where the opt-out default applies, $99 \%$ of individuals do not feel strongly enough to forbid their post-mortem utilization by opting-out. In Denmark, where the reverse applies, only $4 \%$ of individuals are sufficiently beneficent to opt-in. ${ }^{66}$ For Bentham, the disproportion would surely provide an overwhelming justification for changing the default. ${ }^{67}$ Thaler and

\footnotetext{
62 Thaler \& Sunstein, Nudge, 202.

${ }^{63}$ D.M. Housman \& B. Welch, 'To Nudge or Not to Nudge', Journal of Political Philosophy (21) 2010, 123-36, at 125 .

${ }^{64}$ See Quinn, 'Jeremy Bentham, “The Psychology of Economic Man” and Behavioural Economics'.

${ }^{65}$ See Nudge, 227-34, where Thaler and Sunstein list 'A Dozen Nudges', of which is it difficult to see Bentham mounting a principled objection to a single one.

66 This information is taken from D. Kahneman, Thinking, Fast and Slow (London, 2011), 373.

${ }^{67}$ In Bentham's time, medical men deplored the lack of dead bodies on which trainee surgeons might practise. His own 'Auto-Icon, or the Farther uses of the dead to the living' was an effort to challenge prevailing opinion on the post-mortem disposal of bodies, while he also drafted a 'Body-providing Bill', which sought to solve the problem by appropriating the unclaimed bodies of those dying in poorhouses. See UC xi. 220-3, and R.
} 
Sunstein however, are more hesitant and, even though opting out would involve only minimal costs in terms of time and effort, they endorse instead 'mandated choice', under which applicants for a driving licence are obliged to exercise a binary choice between the two alternatives.

The framing of default options addresses interests directly to a modest extent, and thus does address the will (by providing a very modest disincentive to rejection of the default), but the central operation of such framing concerns knowledge, and addresses the understanding. Defaults contain two different kinds of information. The first kind is the message that the provider of the default option endorses the option and recommends acceptance: if they did not, they would not have made it the default. This message is particularly powerful when it comes from an authority whom we trust, to whom indeed, we are looking to supply deficiencies in our own knowledge. The second kind of information contained in defaults is the message that 'This is what most people do', which appeals to our readiness to go along with the crowd. When the choice architect is a Benthamic legislator, it simply behoves her to set utility-maximizing defaults.

\section{Hard cases}

\subsection{Taxes}

Bentham has no doubt that taxation involves coercion: 'to tax is to coerce'. ${ }^{68}$ Fiscal policy features a well-established distinction between direct taxation (levied on income or property and collected directly by government) and indirect taxation (levied on consumption and collected by an intermediary) which does not coincide exactly with that between direct and indirect legislation. In general, Bentham favoured indirect taxes because 'To an indirect tax, each man pays no more than he pleases'. ${ }^{69}$ When confined to luxuries, the potential payer retained the option of avoiding the tax by avoiding consumption of the taxed article. However, taxes, whether direct or indirect, shared an essentially coercive nature: 'The direct effect, of the sort of tax called indirect, is to make a man pay for the use of the article taxed, and go on using it as before: an indirect effect is to make him cease to use it, to avoid paying the tax. This indirect effect is the same as that of a prohibitive law, prohibiting the use of the article,

Richardson, Death, Dissection and the Destitute (Harmondsworth, 1987). Bentham, of course, was publicly dissected after his death, when the idea of transplanting organs to live recipients was long in the future.

68 'Draft Postscript to Defence of Usury' in Writings on Political Economy: Vol. I (CWJB), 140n. See also

'Manual of Political Economy', ibid. 165-214, at 186): 'whatever is yielded in payment of a tax is taken by force'.

69 'Institute', UC xvii. 316 (11 March 1804) (Jeremy Bentham's Economic Writings, III. 366). 
viz. under a penalty equal to the amount of the tax. ${ }^{, 70}$ To the extent that a tax prevents consumption, it is in its effect equivalent to a direct law prohibiting consumption. This is exactly the effect aimed at by the indirect tax on gin, though elsewhere Bentham was less confident of its efficacy: 'By a tax upon Gin, many a man, instead of being sobered, has been starved. ${ }^{71}$ If this is an exercise in indirect legislation, it is so only relatively, that is in matter of degree.

As noted above, Housman and Welch criticize nudge theory for confusing nudges, which are supposed to impose only minimal costs on non-compliance, with coercion: 'An even more egregious example of mislabeling a coercive policy as a nudge appears when Thaler and Sunstein write that a cap and trade system restricting pollution "is compatible with libertarian paternalism, because people can avoid paying the tax by not creating pollution". On that reasoning, libertarians should have no objection to paternalistic "sin taxes.",72 For his part, Bentham endorsed 'sin taxes', for instance on alcohol or ostentatious funeral services, ${ }^{73}$ but opposed the imposition of taxes on 'merit goods', his favourite examples being medicines, newspapers and, of course, access to law. ${ }^{74}$ The description of nudges as not 'significantly changing their [i.e. the chooser's] economic incentives ${ }^{95}$ is also a matter of degree. For example, Thaler and Sunstein report approvingly a proposal to require a special licence and completion of additional driving training as a 'nudge' alternative to mandatory wearing of motorcycle-helmets. ${ }^{76}$ Whether helmets should be mandated by direct legislation would, for Bentham, depend on the outcome of a probabilistic calculation of the pleasures and pains involved in the two strategies. Variations in tax alter the incentives of the tax-payer, though the effects on behaviour depend on a range of other variables, such as her disposable income,

\footnotetext{
${ }^{70}$ Ibid., UC xvii. 289 (11 March 1804) (Jeremy Bentham's Economic Writings, III. 368).

${ }^{71}$ Ibid.

${ }^{72}$ Housman \& Welch, 'To Nudge or Not to Nudge', 125. The criticism is blunted somewhat by Thaler and Sunstein's admission that 'cap and trade' has 'coercive' features, and is thus at best 'a cousin' of libertarian paternalism (Nudge, 196).

${ }^{73}$ For Bentham's endorsement of 'sin taxes' on 'slow poisons' (distilled liquors and opium) and 'articles unfavourable to cleanliness' (tobacco and snuff) see 'Proposals relative to Divers Modes of Supply' (UC clxvi. 39). The same work contains Bentham's endorsement of fiscal discouragement of ostentatious funerals and the trade of undertakers, which 'might be cramped or even demolished without any real prejudice to any body' (ibid., UC clxvi. 141 (Jeremy Bentham's Economic Writings, I. 395)), and involved the obligation of acquiring an expensive licence in order to exercise it. For Bentham, the business is rendered lucrative only by 'the vanity and folly of mankind' (ibid.). In 'Indirect Legislation', UC lxxxvii. 62, Bentham endorses 'encouraging the consumption of uninebriating liquors in preference to such as are inebriating'; see also ibid., UC 1xxxvii. 63, 66 . ${ }^{74}$ See 'Proposals relative to Divers Modes of Supply', UC clxvi. 39; 'Institute', UC xvii. 317 (Jeremy Bentham's Economic Writings, III. 368)); and 'A Protest against Law Taxes' (first published 1795), in Writings on Political Economy: I (CWJB), 269-98).

75 Thaler and Sunstein, Nudge, 6.

${ }^{76}$ Ibid., 231.
} 
the necessity of the taxed article to her future plans, and the availability and cost of untaxed alternatives. In general then, there is a parallel between the distinction between a tax and direct legislation on the one hand, and that between a tax which is a 'nudge' and one which is more of a coercive 'shove' on the other.

\subsection{Defaults, Invalidity, and Self-executing Laws}

The subject of taxation is closely connected, for Bentham, with another expedient of indirect legislation. He introduces it under the title 'Transforming punishment into reward', with the following proposition: 'Let a service of any kind be intended to be render'd gratis. Instead ... let the performance of it be now postponed till after the performance of another service to be render'd by him for whom the first service is designed: such first service is thereby turned into a reward. ${ }^{77}$ Bentham here introduces a particular default position or initial setting, which he then modifies. The default he has particularly in mind is the provision by the state, without specific charge, of a range of enforcement services which bolster security in general, and security of property in particular. The legislator now decides to impose a specific charge for those services by levying a tax on certain legal instruments. The 'service postponed' is the provision in case of need of the relevant enforcement services, while the newly demanded service is the payment of the tax.

Of stamp-acts it has been taken notice of as one very convenient property, that they execute themselves. Let us observe how far this is true, and how it comes to pass. A stamp-duty is imposed upon a particular conveyance. How is the payment enforced? by declaring that the instrument of conveyance if produced without the stamp, shall be looked upon as void. A good conveyance is that which has the public authority in its favour ... . Its efficacy depends upon certain services which upon occasion the ministers of justice are disposed to render to him in whose favour it is made ... . These services the sovereign ... before the imposition of the stamp-duty [was] in the habit of rendering gratis. By the stamp act he ordains that in future ... they shall be sold ... for the amount of the duty, of the receipt of which the stamp is to be consider'd as an acknowledgement. ${ }^{78}$

The law executes itself insofar as the purchaser of the stamp has a strong motive to comply, 'since till he has render'd the service which it belongs to him to render, he is sure of not receiving the service'. ${ }^{79}$ The expedient of the evidentiary stamp removes the need for subsidiary laws directing investigation, prosecution and punishment for non-payment, which would be necessary were the opposite course to be followed, and the validity of the

\footnotetext{
77 'Indirect Legislation' UC lxxxvii. 142.

${ }^{78}$ Ibid., UC lxxxvii. 143.

${ }^{79}$ Ibid.
} 
instrument to remain assumed until conviction for non-payment: 'The money thus obtained of him is obtained without any of the formalities of procedure'; 'you force him not only to accuse himself but to convict and punish himself, and neither he nor any body suspects there is any hardship in the case' ${ }^{80}$

As we have seen, Bentham considers applying the sanction of withholding validity to the production and registration of a range of legal documents. With regard to the difference between direct and indirect legislation, and the place of the latter within Bentham's legislative project, the interesting question is whether the sanction constitutes direct or indirect legislation. With the help of Limits it may, I think, be established that it is an exercise in direct legislation. Thus the penal code, including all the laws it contains which defend the security of persons and their property, relies for its efficacy on exactly those institutions of enforcement the protection of which is in this case withdrawn. The establishment of title to property often depends on evidence of investive acts. Where such title is established, other individuals are placed under an obligation to refrain from interference with such property. The stamp duty abolishes this obligation with respect to every piece of property whose evidence of title does not bear the stamp. It is, in effect and in form, an 'exemptive provision', describing 'circumstances to which the legislator has given the effect of taking an offence out of the case in which it is punishable' ${ }^{81}$ If this is true, then even on his own terms Bentham's description of the sanction of invalidity as indirect legislation, in contrast to the direct legislation alternative of attaching a specific penal sanction to the non-payment of a sum of money, is one more instance in which the direct versus indirect contrast in no way depends upon the non-application of a penal sanction. Bentham thinks that laws of this nature are indirect because they do not operate by the creation and application of a specific penalty and procedure for punishing non-compliance, while that procedure and penalty form essential elements of direct legislation. However, as Bentham himself might say, describing the protection of the law for my property as a reward which I forfeit by the non-payment of the tax, rather than as the very essence of the Legislator's primary duty (to meeting the expense of which all property-holders might reasonably be obliged to contribute $)^{82}$ is a matter of mere

\footnotetext{
80 Ibid.

${ }^{81}$ Limits $(C W J B), 158$. In the terms of Bentham's topographical metaphor, the coercive laws threatening penal sanctions against invasions of property create islands where the general permissiveness is suspended, whilst the exemptive clause carves out of those islands so many lakes where that permissiveness is reinstated with regard to the non-possessors of the property, and in which, with regard to any property depending on certification which lacks the requisite stamp, the threat of the penal sanction is lifted.

${ }^{82}$ As Bentham noted: 'Protection of property is the first duty of the state' (Writings on Political Economy: Vol. I $(C W J B), 143)$. One of the few explicit references to indirect legislation discovered in Bentham's later writings
} 
words. ${ }^{83}$

\section{Indirect Legislation and the Moral Sanction ${ }^{84}$}

\subsection{Legislators all?}

Bentham categorizes a final range of measures as indirect legislation, in which direct

legislation plays no part. One clue to their operation appears in Limits:

The legislator, then, may, in the view of giving efficacy to his laws, take either of two courses: he may trust altogether to the auxiliary force of the two foreign sanctions, or he may have recourse to motives drawn from that fund which is of his own creation.

The former of these courses has sometimes been taken with success: there seem even to be cases where it is to be preferred to any other. These cases, however, are but rare. ${ }^{85}$

In a note, Bentham indicates that discussion of foregoing the operation of the political sanction altogether is contained in the Chapter on indirect legislation. ${ }^{86}$

What do the efforts of the legislator to educate, inform and mobilize the 'foreign' or 'auxiliary' sanctions (the moral and religious) ${ }^{87}$ reveal about indirect legislation? For

Bentham, the relevant questions about the auxiliary sanctions relate respectively to their force

concerns exactly such self-executing laws: see The Book of Fallacies (first published 1824), ed. P. Schofield (Oxford, $2015(C W J B)$ ), 181. For reasons which remain to be fully explained, Bentham appears largely to have dropped 'Indirect Legislation' from his vocabulary after 1800, but his enthusiasm for self-executing laws persisted.

${ }^{83}$ As Bentham noted, 'Indirect Legislation', UC 1xxxvii, 3: 'If, of the expedients which we shall proceed to mention under the head of indirect legislation, there should be some which may appear referable to the other head, it will be no great matter: nothing of moment will turn upon the accuracy of the division.'

${ }^{84}$ Constraints on space necessitate omission of analysis of Bentham's discussion of efforts to act directly on the power of potential offenders: see 'Indirect Legislation', UC xcvi. 257: 'It is evident enough with regard to any offence whatsoever that any expedients by which the progress of it can be checked without the expence of punishment are better than any which consist in punishment; that physical obstacles are much better than moral ones to set up against an offence; and that it is much better to make an offence, physically speaking, more difficult to commit than it was before, than it is to leave it as easy as it was before; and render it more penal.' Itai has drawn attention to measures which control behavior by directly manipulating the architecture of the physical environment ('Bentham's Indirect Legislation', in Utilitarianism and the Theories of Policies. ed. M. Otanashi, Tokyo, 2011), for instance preventing the homeless from sleeping on benches by building benches on which it is impossible for a human being to lie flat. This is a classic piece of indirect legislation against vagrancy which operates directly on power. However - setting aside questions about the mischievousness of vagrancy, and whether such expedients are the least painful way to obviate it-the range of cases which seek to combat mischief by the direct manipulation of the architectural environment seems likely to be limited. As Bentham noted, 'In the taking away of physical power the sphere of legislative operations, upon the principle of utility can hardly be very extensive'; 'In these cases, the policy of the senate may be compared to the policy of the nursery, in which the windows are fenced round with iron bars, the fire-place with high fenders, and knives and scissors laid up carefully out of reach.' ('Indirect Legislation', UC lxxxvii. 92, 93).

${ }^{85}$ Limits, $(C W J B), 142$.

${ }^{86}$ At the risk of labouring a point, Bentham certainly categorizes measures of this nature as indirect legislation, but he does not state that indirect legislation is limited to such expedients. Indeed, any such assertion would involve him in a flagrant inconsistency. Of an intended twenty-three sections or Chapters in 'Indirect Legislation', twelve were to deal with the 'indirect' deployment of direct legislation, while five were to deal with the moral and religious sanctions: see 'Indirect Legislation', UC lxxxvii. 5.

${ }^{87}$ For reasons of space, the ensuing discussion focuses exclusively on the moral sanction. 
and their direction. The first question asks how powerful the means of extra-legal punishment and reward are; the second asks whether extra-legal punishment and reward are applied in a manner consistent with utility. In relation to the first question, the core variable in the distribution of pains and pleasures by the moral sanction is reputation, or good name. One easy route to social acceptability, to the good offices which flow from possession of a good name, is to think and act like our peers. Partly because agreement is more pleasant than disagreement, human beings tend to think in herds. Many of Thaler and Sunstein's nudges trade on this desire to fit in, and a Benthamic legislator would be foolish not to recognize this fact of human psychology.

Regardless of its direction, the moral sanction possesses a considerable degree of force, which is exploited by the set of expedients for disseminating knowledge discussed in $\S$ 3. There is a parallel here with Bentham's deployment of an informed public in preventing political misrule, and maladministration in a wide variety of institutions. Hence his insistence, repeated in 'Indirect Legislation', that the force of the moral sanction depends upon the liberty of the press. ${ }^{88}$ For the most part, he is content to empower the moral sanction. Indeed, his entire mature constitutional project might accurately be described as the attempt to institutionalize the continuous dependence of public office-holders on public approval. ${ }^{89}$ However, insofar as the direction of the moral sanction is incorrect-insofar, that is, as public opinion punishes harmless actions and rewards mischievous ones-empowering the moral sanction will result in consequences far removed from the dictates of utility.

How can the Legislator guide public opinion? First, she can attempt to educate it. Bentham's favourite examples in this regard are smuggling (a mischievous practice tolerated by public opinion) and informing against offenders (a beneficial practice condemned by public opinion). It behoves the Legislator to address the understanding of her subjects, that is their knowledge, in order to change their will. In one sense, this somewhat utopian strategy looks diametrically opposed to that of 'Nudge', with its exploitation of human cognitive shortcomings to good ends. Ultimately, the Legislator's ability to convince the people should depend upon nothing but the quality of her argument; on nothing but, that is, the soundness of her probabilistic judgment of the production and distribution of pleasures and pains experienced by human beings in consequence of the attitude in question. This is Bentham in

\footnotetext{
88 'Indirect Legislation', UC lxxxvii. 18.

${ }^{89}$ See F. Rosen, Jeremy Bentham and Representative Democracy: a study of the Constitutional Code (Oxford, 1983); Lieberman, 'Bentham's Jurisprudence and Democratic Theory', 132-42.
} 
his most characteristically Enlightenment mode of thought, combatting prejudice with the cool light of reason, and directly seeking to address the understanding of his audience.

There is, however, another strand to his approach, which is reminiscent of the alleged response of Adlai Stevenson when assured that his arguments had surely won the vote of every thinking person, 'That's not enough Ma'am, we need a majority'. The Legislator too needs a majority — literally and explicitly under the Constitutional Code, and implicitly (in the negative sense of not provoking a critical mass of disobedience) even in Bentham's earliest writings - and Bentham is realistic enough to recognize many of the cognitive foibles which Nudge theory exploits, and is equally prepared to exploit them. More generally, he recognizes the interplay between will and understanding, and is perfectly willing to endorse an approach which either bypasses or supplements argument with a direct, and preferably dramatic, appeal to emotion: 'Guérison des principes par des raisons, par des exhortations, par des coups de théâtre. Mouchoir présenté en cérémonie par le juge ou le souverain (selon le rang) aux parens d'une personne condamnée à peine infamante, pour essuyer leur pleurs.' 90 Having the best argument is one thing, but being, in modern parlance, the best spin-doctor, might well count for more.

One set of expedients relies on the provision of appropriate images to harness the power of pre-existing positive or negative associations, and thus to colour public perceptions of novel phenomena. In Dumont's version of 'Indirect Legislation', the shrewd exploitation of the positive public perception of the Empress in Russia is reported as having successfully assuaged popular fears about the innovation of inoculation:

The most powerful method of producing an important revolution in public opinion is to strike the mind of the people by some noble example. ... Thus Catherine II surmounted the popular prejudice against inoculation, not by trying it upon some criminals, as was done in the reign of Queen Anne, but by submitting to it herself. ${ }^{91}$

\footnotetext{
${ }^{90}$ UC xcix. 152, brouillon for 'Projet' (emphasis added).

91 'Of Indirect Means of Preventing Crimes', Bowring, I. 533-80, at 564 (Traités, III. 1-199, at 133; Traités 2010, 331-405, at 382). This example does not appear in the text of Bentham's draft of 'Indirect Legislation', but it does appear in one of his marginal contents sheets for the work at UC xcix. 110: 'Cath. II inoculated herself. Regis ad exemplum totus componitur orbis' (i.e. 'The world shapes itself after the King's pattern'. See Claudian, Panegyricus de Quarto Consulatu Honori Augusti, 316-17). A similar idea appears in his poor law writings, where he alludes to his proposal for identity marks after proposing that persons with no visible means of support should be liable to examination as to their means of livelihood. Using the analogous appeal to the principle 'If it's good enough for them it's good enough for me', he imagines George III's responses to such questions: 'I am your King-my business is to govern you.' (Writings on the Poor Laws: Vol. II (CWJB), 239n.)
} 
Elsewhere, Bentham criticizes the fallacious use of negative associations as substitutes for argument, according the proverb 'Give a dog bad name and hang it' ${ }^{92}$ Here however, he advocates utilizing pre-existing attitudes to produce beneficial consequences.

British readers of my age might recall two striking images in this connection. The first is that of John Gummer, Minister for Agriculture, feeding a beef-burger to his daughter Cordelia at the time of the outbreak of BSE, and delivering, for public consumption, the implicit message 'This beef is safe, and to prove it my own flesh and blood will eat it'. The second is of Princess Diana, at the time when AIDS made its appearance, and levels of hostility to AIDS patients were high, visiting, and even (heaven forfend!) touching them. These interventions varied in their effects. On the one hand, John Gummer's efforts largely failed to restore public confidence in British beef; on the other, notwithstanding my own republican sentiments, Diana did more by that single heavily publicized act to normalize the disease, and to re-humanize people suffering from AIDS, than any legislation or public information campaign.

What might these examples tell us about indirect legislation? They were certainly acts of highly symbolic communication, but were they acts of legislation, of law-making? By no means obviously. Were they carried out, suggested or facilitated by government? In the first case, yes; in the second, I very much doubt it. Would Bentham regard them as indirect legislation? I think he would, for two reasons. First, while Bentham's characterizations of indirect legislation often feature explicit reference to law, ${ }^{93}$ at least one expands the field to include 'all other expedients whatsoever which can contribute to the production of the proposed effect'. ${ }^{94}$ According to the first characterizations, neither Catherine the Great nor

\footnotetext{
${ }^{92}$ Defence of Usury, Shewing the Impolicy of the present legal restraints on the terms of pecuniary bargains (first published 1787), in Writings on Political Economy: Vol. I (CWJB), 43-121, at 77. In The Book of Fallacies $(C W J B)$, Bentham discusses several fallacies which make deceptive use of pre-existing positive or negative associations, and which, in relation to the latter, effectively consist in 'the effort to turn aside the attention of the hearer or the reader from the measure to the man' (ibid., 292). As Bentham continues: 'The measure in question being a good one, a bad man, be [he] ever so bad, the support given by him to this good measure, can it have any such effect as that of converting it into a bad one?' (ibid. 294). The proper criterion of evaluation, that is the probable consequences of the measure for the experience of pleasure or pain by sentient beings, is lost from view, and replaced by the positive or negative emotional response to its proposer. We say to ourselves, I don't like him, therefore his proposal is bad, and thus surrender to anyone, people who wish us harm included, who is able to associate a measure with some person or group we do not like: 'Give yourself up to any such blind antipathy, you are put no less in the power of your adversaries, than, by a correspondently irrational sympathy and obsequiousness, you put yourself in the power of your friends' (ibid.). See also ibid., 83-94, 291304, 473-5, 482-5.

${ }^{93}$ See, for instance, 'Indirect Legislation', UC lxxxvii. 2-3, where indirect legislation is defined as 'whatever else [i.e. excepting direct legislation] can be done in the way of law in subservience to the same end' (emphasis added).

${ }^{94}$ Ibid., UC lxxxvii. 3.
} 
John Gummer nor Diana were engaged in indirect legislation, but according to the second, they all were.

Two contrasting points might be made. First, such expedients expand the concept of legislation to encompass everything that governments or sovereigns do, from the enactment of generally applicable coercive statutes at one end of the continuum, through particular administrative rules and decisions, to public service announcements, interviews, pressreleases and tweets at the other. Second, the notion that Diana was legislating indirectly expands the concept more exponentially, since analogous behaviour is not the exclusive remit of the legislator. Several times in 'Indirect Legislation', Bentham identifies Hogarth as, in effect, an indirect legislator. ${ }^{95}$ Now Hogarth was an artist who helped to form and guide public opinion in relation to a range of issues, but he was not a law-maker. In this sense, indirect legislation is open to anybody with either a convincing argument or a smooth and pleasure-producing delivery of any product or message which the public will buy (in both senses of the word). Laval recognizes this extension of legislative initiative, ${ }^{96}$ and goes on to argue that this democratizes indirect legislation, rendering Bentham's good society one characterized by maximal reciprocal transparency and control. ${ }^{97}$ Bentham often does seem to endorse such reciprocal inspection, on the basis that the more our actions are exposed to scrutiny, the greater the leverage of the moral sanction, and the more we will internalize that sanction: 'the more strictly we are watched, the better we behave'. ${ }^{98}$

However, at other times, in relation to other issues, he argues that popular opinion is often wrong-headed. Even in 'Indirect Legislation', he notes with reference to efforts to regulate consensual sex outside marriage: 'In general the great object is to bring about detection: here the object is to prevent it: since it is from the detection rather than from the act that the mischief takes its rise. ${ }^{99}$ Similarly, Bentham spent sixty years arguing in private that British attitudes to homosexuality were a mischievous amalgam of asceticism and caprice. ${ }^{100}$

\footnotetext{
${ }^{95}$ See ibid., UC xcvi. 258: 'Thus did the Legislators betake themselves to play off the political Sanction against this baneful habit [i.e. gin-drinking].- Hogarth meantime, with admirable spirit and ingenuity, plaid off the Moral'; see also ibid. 1xxxvii. 27, 66.

${ }^{96}$ See 'The Invisible Chain', this issue, 000: 'It is not only the work of the legislator which is concerned, but also that of the deontologist, the journalist, the economist and the educator.'

${ }^{97}$ Ibid., this issue, 000: 'It diffuses and distributes as widely as possible the means for individuals to keep a check on others. In reality, the type of society Bentham so remarkably anticipates is more a society of generalized mutual control, the effect of which is to normalize interests, guarantee the expectations of individuals vis-à-vis others, and maximize the product of actions.'

${ }^{98}$ Writings on the Poor Laws: Vol. I (CWJB), 277.

99 'Indirect Legislation', UC 1xxxvii. 128.

${ }^{100}$ See, for instance, Of Sexual Irregularities (CWJB), 9-24, 66-78, 129-32, 135-6.
} 
In that context, reciprocal transparency would involve severe pains for homosexuals. ${ }^{101}$ In addition, this 'democratization' of legislative initiative opens the possibility that riches and influence, rather than quality of product or of argument, will win out in political and economic competition. Housman and Welch berate Thaler and Sunstein for manipulatively imposing governmental preferences on unsuspecting citizens, but seem remarkably unconcerned about such manipulation when undertaken by corporations. ${ }^{102}$ Bentham might insist, with Thaler and Sunstein, that since there is no such thing as a decontextualized choice, the removal from government of the capacity to spin their message in the best light opens the door not to liberty, but to the arbitrary exercise of private power.

If public opinion may indeed, as Bentham argued late in life, 'be considered as a system of law, emanating from the body of the people', ${ }^{103}$ then everybody who contributes to the formation of public opinion is potentially a legislator. The dictates of public opinion are, like other laws, declarations of will. Like the Common Law, or customary law in general, they lack definitive form, but, like the Common Law, that failing does not prevent their influencing behaviour. ${ }^{104}$ The leaders of public opinion are in a position to issue unacknowledged legislation. This might open up an attractive vista wherein a vigorous and informed public debate the legitimacy of all exercises of power, including its own, ${ }^{105}$ or a dystopian nightmare wherein an unthinking herd adopt irrational antipathetic prejudices. In terms of legal theory, the problem is that it threatens to make Bentham's theory of law a great deal less straightforward, and to expand the concept of law so broadly that it ceases to be applicable in normative analysis.

\subsection{Fooling the people}

In his recension of 'Indirect Legislation', Dumont features an example of governmental duplicity which exploits the emotional power of a pre-existing negative association. 'There is a secret art of governing opinion, so that it shall not perceive, so to speak, the manner in which it is led. It consists in so disposing matters, that the act to be prevented can not be

\footnotetext{
${ }^{101}$ See 'Place and Time', edited by P. Schofield and S. Engelmann, in S. Engelmann (ed.), Jeremy Bentham: Selected Writings (New Haven \& London, 2011) 152-219, at 162-3 (Bowring, I. 169-94, at 175), where Bentham noted 'were it even altogether unpunishable by law ... the consequence of being reputed guilty would be attended with a degree of infamy which can be compared to nothing so properly as that which attends forfeiture of caste among the Hindoos'.

${ }^{102}$ Housman \& Welch, 'To Nudge or Not to Nudge', 131.

${ }^{103}$ Constitutional Code: Vol. I, ed. F. Rosen and J.H. Burns (Oxford, 1983 (CWJB)), 36.

${ }^{104}$ See Postema, 'The Soul of Justice: Bentham on Publicity, Law, and the Rule of Law', in Bentham's Theory of Law and Public Opinion, 40-62, at 61.

${ }^{105}$ See O. Ben-Dor, Constitutional limits and the public sphere: A critical study of Bentham's constitutionalism (Oxford, 2000).
} 
performed, without also performing an act which popular opinion has already condemned. ${ }^{106}$ Concerned about a rash of violent attacks, facilitated by the prevailing fashion for voluminous cloaks and hats under which weapons might be concealed, the Spanish government formed its primary will (such hats should not be worn) and issued direct legislation to that effect, only to find it had provoked such discontent that riots broke out, and the law was rescinded. 'A short time after this triumph of the round hats, the Count d'Aranda being made Minister, he enjoined all the executioners ... to wear round hats. In a fortnight, no more round hats were seen.' ${ }^{107}$ The successful move was to excise all reference to the primary will, and to rely instead on the widespread disinclination to be mistaken for a public executioner. Was d'Aranda making a law? Certainly, in so far as he declared his will in his instruction to officials, his 'enjoining'; it was even a direct law if accompanied with penalties for non-compliance. The point however, is that the effectiveness of the ploy would have been reduced, if not eliminated, by public disclosure of its rationale. 'I want you all to stop wearing round hats, but I told you so, and you rioted. Therefore, all executioners will wear the hats you like so much, and my expectation is that you will suddenly find them less appealing.' To resentment against the primary will would be added resentment against being manipulated: instead of reducing the incidence of round hat wearing, d'Aranda might provide an additional motive for it, since now this article would carry an extra symbolic message to the effect that the wearer had no intention of being manipulated. Do such strategies therefore conflict with Bentham's commitment to transparency, and with his demand for union of rule with rationale? The answer can only be in the affirmative.

There is a tension between appearance and reality, between subjective perception and objective fact, which runs throughout Bentham's theory of punishment, and which appears again in 'Indirect Legislation'. The exploitation of appearance over reality clearly involves the potential for deception: 'Humanity consists in seeming to be cruel'. ${ }^{108}$ The problem for such deception is that the evidence of sense is equally available to all of us, and the likelihood is that some of us will penetrate appearance and perceive reality: we will, in other words, find out that we have been had, and presumably react with indignation.

\footnotetext{
106 'Of Indirect Means of Preventing Crimes', Bowring, I. 563 (Traités, III. 131; Traités 2010, 381).

107 'Of Indirect Means of Preventing Crimes', Bowring, I. 563-4n. This example does not feature in the first edition of Dumont's Traités, and was only introduced in the second edition, 3 vols., Paris, 1820, II. 317-18n. Pedro Pablo Abarca de Bolea (1718-98), Count of Aranda, headed the ministry in Spain from February to November 1792.

108 'Indirect Legislation', UC 1xxxvii. 137; and see also The Rationale of Punishment (London, 1830), 29 (Bowring, I. 390-525, at 398): 'If hanging a man in effigy would produce the same salutary impression of terror upon the minds of the people, it would be folly or cruelty ever to hang a man in person.'
} 
Does this tension, and Bentham's readiness to exploit the cognitive failings of his audience, render all such exploitation (and all nudges) illegitimate? Not necessarily. BozzoRey is right that many of Thaler and Sunstein's attempts to improve both public policy and individual decision-making are inherently public, that is, they depend upon making us all more aware of our cognitive limitations. ${ }^{109}$ However, it certainly delegitimizes any exploitation of irrationality which is not stated in the rationale of the nudge, and thereby undercuts any nudge which relies on my ignorance of its intent for its effectiveness. In one sense, behavioural economists might be thought of as indirect legislators in the same sense as Hogarth or Princess Diana. Rather than advising governments on the best ways to get people to do whatever it is they want them to do, such writers might address a general readership, and be engaged in a transparent attempt to assist us all in making more rational decisions. In this sense, Bentham might well see a role for behavioural economists as deontologists, in 'pointing out to each man on each occasion what course of conduct promises to be in the highest degree conducive to his happiness'. ${ }^{110}$

The tendency of human beings to think in crowds also opens up the behaviourist dream (or nightmare) of solving all problems of criminality by so ordering public consciousness that offences become unthinkable, that is, literally inconceivable. Bentham noted that 'Indirect Legislation operates by causing men not to have certain desires, instead of thwarting them when they are arisen. ${ }^{111}$ His behaviourist psychology led him to boast that the governor of a panoptic school possessed the power to make his pupils convinced of anything, ${ }^{112}$ although he described the passage in question as something of a joke, a 'jeu d'esprit'. ${ }^{113}$ If Bentham were to have indulged this fantasy seriously, indirect legislation might allow the skilful manipulator of public opinion to render her citizens literally impeccable, sinless, since it would simply never occur to them to commit crime. Such an intervention would attack the motives to crime at the very beginning of the chain of causes which issues in offences, but would conflict with Bentham's commitment to transparency. To

\footnotetext{
${ }^{109}$ See Bozzo-Rey, 'From Indirect legislation to Nudge'. Thaler and Sunstein, Nudge, 244, endorse a principle of publicity which 'bans government from selecting a policy that it would not be willing and able to defend publicly to its own citizens'.

110 'Deontology', in Deontology Together with A Table of The Springs of Action and the Article on Utilitarianism, ed. A. Goldworth (Oxford, 1983 (CWJB)), 123. In just this spirit, Lowenstein and Ubel recommend that the target audience for the discipline should be individuals rather than governments: see $\mathrm{G}$. Lowenstein and P.A. Ubel, 'Hedonic adaptation and the role of decision and experience utility in public policy', Journal of Public Economics 92 (2008), 1795-1810.

111 'Indirect Legislation', UC xcvi. 257.

112 Panopticon, or the Inspection House (first published 1812), Bowring, IV. 37-172, at 65: 'Two and two might here be less than four, or the moon might be made of green cheese'.

113 Ibid., 40.
} 
explain to you the benefits which society derives from your inability to imagine theft, for instance, I have to explain to you what theft is. Once I have done that, theft is no longer 'unthinkable' for you, since I have taught you to think it. In fact, Bentham explicitly imagines the demand for such a strategy being put to the Legislator:

"Any body can punish criminal propensities when carried into act. What we want of you and what you will be able to perform, if you understand your art in the degree in which we expect you should understand it, is to teach us how to prevent these propensities from ever being formed-The business is to nip them in the bud, not to let them stay till they have born fruit-Do this or you do nothing." Such is the task which the well-meant but inconsiderate zeal of philanthropists would impose upon the reforming legislator. ${ }^{114}$

Having posed the question, Bentham responds that to expect the Legislator to give such an undertaking is to indulge in an utopian fantasy, where utopian means, as it always does for Bentham, the production of effects in the absence of causes. Given the psychological uniformity of human beings (their common subjection to the natural desire to seek pleasure and avoid pain), the limited availability of the sources of pleasure, and the ubiquity of temptation to reap where others have sown, the demand will remain forever unmet:

They seem to suppose that in some odd corner of the storehouse of possibilities there is a method by which, were human sagacity ingenious or industry fortunate enough to find it out, crimes might be prevented, without the expence of punishment ... . This all powerful institution must needs be as brilliant in itself as it is rare and excellent in its effects. It must be something of a cast very different from ... those vulgar expedients by which the same ends are endeavoured to be compassed in the routine of Legislation. ${ }^{115}$

The Legislator can identify dangerous pleasures, and take steps to divert the demand for them-for instance by refraining from taxing, and by encouraging the taste for, less noxious alternatives ${ }^{116}$ _ but there are limits to her ability to shape tastes. It would be a mistake to view all indirect legislation as essentially deceitful. However, at least in 1782, Bentham himself seems to leave open significant scope for deception: 'In Indirect [legislation] he [i.e. the Legislator] nets everything by imperceptible wires, keeping himself behind the curtain'. ${ }^{117}$ To the extent that indirect legislation involves duping the public, it conflicts with Bentham's commitment to transparency. Conversely, much indirect legislation involves not the withholding of knowledge, but the sharing of it. The latter approach sits foursquare in line with Bentham's standard commitment to transparency, and its rationale is exactly the same.

\footnotetext{
114 'Indirect Legislation', UC lxxxvii. 12 (emphasis added).

115 Ibid., UC lxxxvii.11-12 (emphasis added).

${ }^{116}$ Hence the Chapter 'Diverting the Current of the Desires', in 'Indirect Legislation', UC lxxxvii. 59-65

${ }^{117}$ Ibid., UC xcvi. 257.
} 
On the one hand, the objective, rationalist, Enlightenment Bentham wants to focus on improvement by communication of truth, of facts, between understanding and understanding. On the other, the subjective and, to be self-consciously anachronistic, 'post-modern' Bentham, aware of both the constructivist nature of the world created by human imagination, and of the weaknesses of human rational and cognitive processes, entertains the manipulation of popular will by the manipulation of popular perceptions.

Arguably, the two approaches come head to head in the Book of Fallacies, Bentham's democratic primer for the detection of political deception. Here, the Enlightenment Bentham invests a massive effort in analysis of political fallacies, and in the serial exposure of the errors of inference on which they depend, in the hope that political debate might be cleansed of deceit, and political advantage rendered dependent on appeal to objective facts. Bentham briefly discusses what he calls 'counter-fallacies', and the idea, expressed by a supposed defender, that

'Such is the infirmity of the human character (they may say), that these arguments, weak and inconclusive as they are, are those which, on the minds of the bulk of the people upon whom ultimately every thing depends, make the strongest and most effectual impression: the measure is a most mischievous one: it were a crime on our part to leave unemployed any means not criminal that promise to be contributory to its defeat. It is the weakness of the public mind, not the weakness of our cause, that compels us to employ such weapons in the defence of it.'

This defence may indeed be received as adequate where the fallacies in question, or any other irrelevant and indirect arguments, are employed — not as substitutes, but only as supplements, to relevant and direct ones.

But if employed as supplements ... two conditions seem requisite:

1. That arguments of the direct and relevant kind be placed at the front of the battle, [and] declared to be the arguments and considerations by which the line of conduct embraced in opposition to the proposed measure was produced.

2. That, on the occasion of the irrelevant and indirect arguments in question, an acknowledgement should be made of their true character - of their intrinsic weakness - of the consideration which ... seemed to impose ... the obligation of employing them - and of the feeling of regret with which the consciousness of such an obligation was accompanied. ${ }^{118}$

By 1810 then, Bentham seems to have decided, unsurprisingly given his commitment to democratic politics, that appeal form understanding to understanding constitutes the only legitimate mode of political argument, and that the fallacious nature of counter-fallacies

${ }^{118}$ The Book of Fallacies (CWJB), 52-3. See also ibid., 87. 
should be identified even in those limited cases where tactical considerations permit their temporary deployment. ${ }^{119}$

\section{Conclusion}

What conclusions should be drawn from the evidence set about above, about the relationship between indirect legislation and Bentham's general project of 'rearing the fabric of felicity by the hand of reason and law'? ${ }^{120}$

1. For Bentham, the entire task of law consisted in the effort to shape the architecture (normative, physical and psychological) of choice. This characterization applies equally and alike to direct and to indirect legislation.

2. Much indirect legislation actually consists of measures of direct legislation considered from a different perspective.

3. Much indirect legislation involves not the witholding of knowledge, but the sharing of it. Where interest can be relied on to operate to the elimination of offences, the Legislator's direct provision of knowledge, or instruction to others to make such provision, is often all that is required. If the moral sanction is to be utilised in modifying behaviour by supplying punishments and rewards, such provision of knowledge may once again be crucial: public opinion cannot sanction that of which it remains unaware.

4. It is likely that Bentham would nudge, and more than nudge. The idea of exploiting our inveterate idleness to make us better off, but allowing us to decline the offer at small cost would likely make him happy. His commitment to the premise that individuals are the best judges of their own interests is considerable, but by no means absolute. Given the cognitive failures revealed by behavioural economics, of course governments should nudge in the direction of maximizing utility.

5. If Bentham did intend indirect legislation to embrace all governmental engagement with the public, both coercive and non-coercive, he risked thereby inflating the concept of law so much that it threatens to become meaningless.

6. Insofar as public opinion is a system of law, every individual is a potential legislator. Again, this reading threatens to undermine the determinacy of Bentham's concept of law.

\footnotetext{
${ }^{119}$ Of course, it remains true that since many nudges operate below the level of conscious reflection and argument, the demand that the explicitly utilitarian arguments should take the lead fails to affect interventions which feature no explicit rationale.

${ }^{120}$ IPML (CWJB), 11.
} 
7. Bentham does have an issue with the distinction between reality and appearance, between the subjective and objective strands of his thought. In general, the universal availability of the evidence of sense makes the systematic exploitation of the gap between perception and reality a hazardous business for unwary Legislators, but there may be circumstances in which fooling the public for their own good is justifiable on utilitarian grounds.

8. In relation to any act, choice, or individual decision-point, the utilitarian legislator has several options. First, do nothing: make no conscious effort to tilt the choice architecture in the direction of maximizing utility. Second, address the understanding by supplying information and, at need, explicit advice. Third, nudge: supply good models and utilitarian defaults, exploit the popularity of particular role models and the influence of pre-existing positive or negative associations, and encourage the production and dissemination of moral lessons, but impose only minimal costs on non-compliance. Fourth, use direct legislation in an indirect way, by prohibiting or mandating actions related to, but distinct from, the act which is the target of the Legislator's primary will. Fifth, use direct legislation proper, in which that primary will is obvious on the face of the law. The choice between these options will be determined by the calculation of the pleasures and pains consequent upon the choice in particular instances. Thaler and Sunstein have been criticized for offering no critical standard by which to identify a good or rational choice. ${ }^{121}$ Bentham looks immune from such indictment: for him, a good or rational choice is one which produces a net balance of pleasure over pain for the persons whose interests are affected by it, while the best choice is that which produces the largest such balance.

\footnotetext{
${ }^{121}$ See, for instance, B. McQuillin and R. Sugden, 'Reconciling normative and behavioural economics: the problems to be solved', Social Choice and Welfare 38 (2012), 553-67, at 560; S.P. Hargreaves Heap, 'What is the meaning of behavioural economics?', Cambridge Journal of Economics 37 (2013), 985-1000.
} 